\title{
Aurora Kinase C
}

National Cancer Institute

\section{Source}

National Cancer Institute. Aurora Kinase C. NCI Thesaurus. Code C95267.

Aurora kinase C (309 aa, $\sim 36 \mathrm{kDa}$ ) is encoded by the human AURKC gene. This protein is involved in protein phosphorylation that mediates centrosomal activity during mitosis. 